UDC 271.222(497.11)-526.62"04/14"

https://doi.org/10.18485/ms_zmslu.2021.49.2

Original scientific paper

Dragana S. Pavlović

\title{
PORTRAITS OF NOBILITY IN SERBIAN MEDIEVAL ART. A CONTRIBUTION TO THE STUDY OF THEIR ICONOGRAPHY
}

\begin{abstract}
Portraits of Serbian nobility, representatives of various social categories that were created in the $14^{\text {th }}$ and in the first half of the $15^{\text {th }}$ century, were preserved in Serbian mural and icon painting. The main goal of this paper is to study and form a comprehensive view of iconographic solutions in the portrait ensembles of Serbian nobility. An exhaustive and detailed analysis has demonstrated that they are diverse and composed of different elements, motifs or formulas. Iconographic models applied to the portraits of Serbian nobility in wall painting of medieval churches, and icon painting, represent a combination of both old models as well as rare and novel solutions. According to their disparate iconography and the appearance of unusual examples, the portraits of Serbian nobility maintain an exceptional place within medieval art.
\end{abstract}

KEYWORDS: Serbia, nobility, iconography, portrait, wall painting, icon painting.

From the period of reign of King Milutin (1282-1321), until the fall of the Serbian Despotate in 1459, the influence of the ruling classes grew and strengthened, as well as their importance within the Serbian state. Having significant material resources at their disposal enabled the most prominent Serbian nobles, as well as members of the middle and lower ranks of nobility, to commission icons, offer donations to the temple or become ktetors of church buildings and fresco painting. Thus, they acquired the right to be portrayed in their own endowments, namely, the temple in the construction or decoration of which they participated in. Hence, in Serbian monumental and icon painting of the $14^{\text {th }}$ and the first decades of the $15^{\text {th }}$ century, an entire series of portraits of nobility had been created. Since the largest number of the portrayals of aristocrats are ktetor portraits in which the nobleman-ktetor is represented alone, that is, with members of their immediate and extended family, on this occasion, we will mostly discuss the aforementioned type of portrayals of Serbian nobility, that is, the iconographic models applied in the presentation via wall paintings in medieval churches. Additionally, based on the preserved fine art material,

* University of Belgrade, Faculty of Philosophy, drpavlov@f.bg.ac.rs 
the paper will also analyse other types of presentations of nobility, such as benefactors and representative portraits of aristocrats, as well as depictions of donors on icons. Judging by the preserved examples, the iconographic solutions in portraits of Serbian nobility are diverse and consist of various elements, motifs or formulas, for instance, the submitting of the model of the endowment to the patron of the temple or the God, without intermediaries, gift offerings to the patron or the God through a representative, the iconography of joint ktetorship, the portrayal of the nobleman-ktetor without the model of the church, the iconography of Christ's blessings, the iconography of deep proskynesis, posthumous portraits of nobility, and depictions of donors within gospel scenes. At times, the portrayals of Serbian nobility had one of the discussed elements, motives or formulas applied, while some, as we shall witness, had the two solutions combined and, simultaneously, allowed for more complex iconographic ensembles to be created.

Regardless of whether considering family or individual portraits, the depictions of the donors in a standing position, frontally or in half-profile in front of the patron to whom they offer the model of the church are most common in the iconography of the ktetorial compositions of Serbian nobility. Considering that the Holy Mother of God is the patron of temples in Kučevište, White Church of Karan, Dobrun, and Mali Grad on Prespa, portraits of the ktetors of said churches and members of their families are gathered around her representation. In Kučevište, the image of the endowment is brought to the Holy Virgin, depicted on the eastern part of the north wall of the narthex, by members of the noble family responsible for the construction and fresco paintings of the church (РАСОлкОскА-НиколовскА 1985: 48-49, fig. 1, 8; ЂорЂЕвит 1994: 135, draw. 34-35). The model is held between them, by Marena, and another, variously identified person, while behind them, on the western part of the same wall, Jovan, son of voivoda Dejan and voivoditsa Vladislava is presumably depicted. ${ }^{1}$ In the White Church of Karan (fig. 1), and portrayed on the west side of its northwest pilaster, župan Petar Brajan, accompanied by his wife and four daughters, submit the model of the church to the Holy Mother of God (Волводић 2006-2007: 146-147, fig. 8, 9). In Dobrun, the ktetor, župan Pribil, together with his sons, depicted on the south wall of the narthex, originally offered his gift to the Holy Mother of God with Christ in her arms (ЂорЂЕвИЋ 1994: 143-144, fig. in colour 8). ${ }^{2}$ In Mali Grad on Prespa, however, the Holy Mother of God is placed in the centre of the composition, to her right are portraits of kaisar Novak and kaisarissa Kali, and to her left are the depictions of the ktetor's children, daughter Marija and son Amiralis (ЂоръЕвић 1994: 177, fig. 84-85). Furthermore, in the nave of Lesnovo (fig. 2), sebastokrator Jovan Oliver presents his gift to the patron Archangel Michael (ЂорЂЕвИЋ 1994: 154; ГАБЕлић 1998: 112-113, Т. I, fig. 46), and in Psača (fig. 3),

${ }^{1}$ Voivoditsa Vladislava (РАСОлКОсКА-НИКОЛОвСКА 1985: 49) or Radoslav (ЂОРЂЕВИЋ 1994: 135) were recognised in the figure of the person depicted next to Marena, while the figure of a young aristocrat, prior to the inscription noticed next to him (БОРБЕвИТ 1994: 135), had been recognised as nobleman Radoslav (PAСОЛкОСКА-НИКОЛОВСКА 1985: 49).

2 This is regarding a standing figure of the patron facing the ktetor, which was placed on the western side of the southern pilaster of the Dobrun temple until World War II, when it was destroyed (ЂоРЂЕВИЋ 1994: 143). 


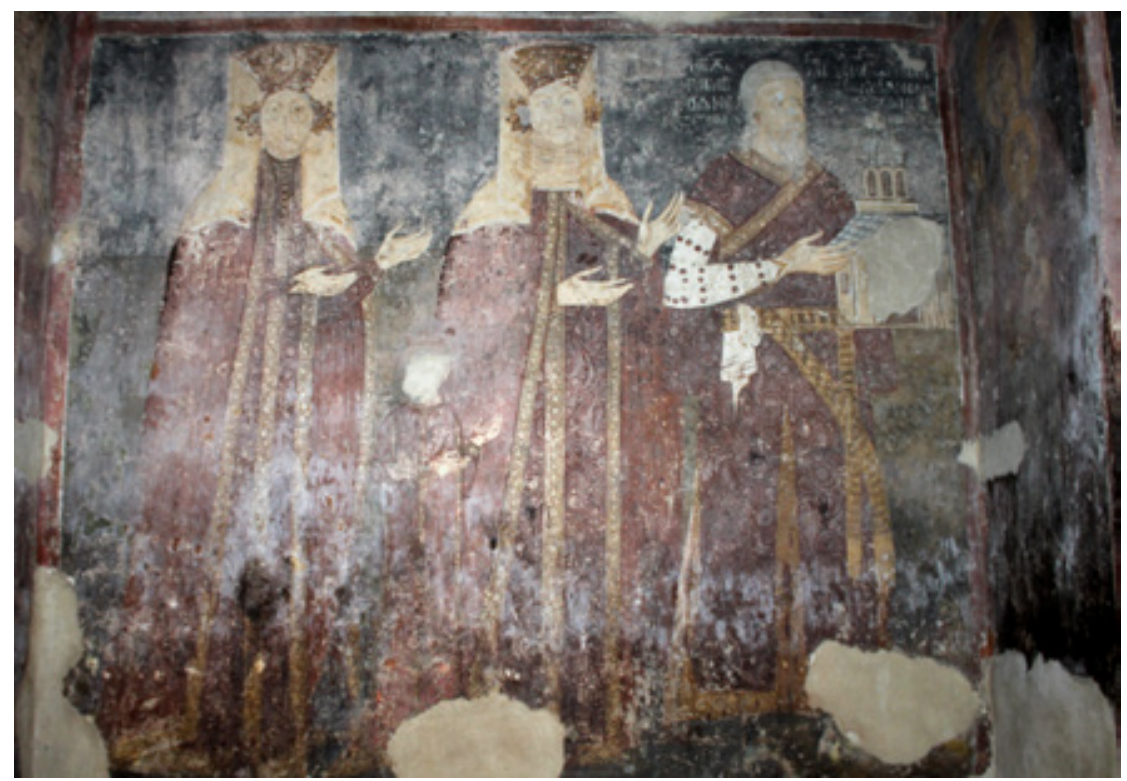

Fig. 1. Church of the Annunciation of the Virgin in Karan, nave, northern wall, župan Petar Brajan, županica Struja and two daughters (photo: I. M. Đorđević)

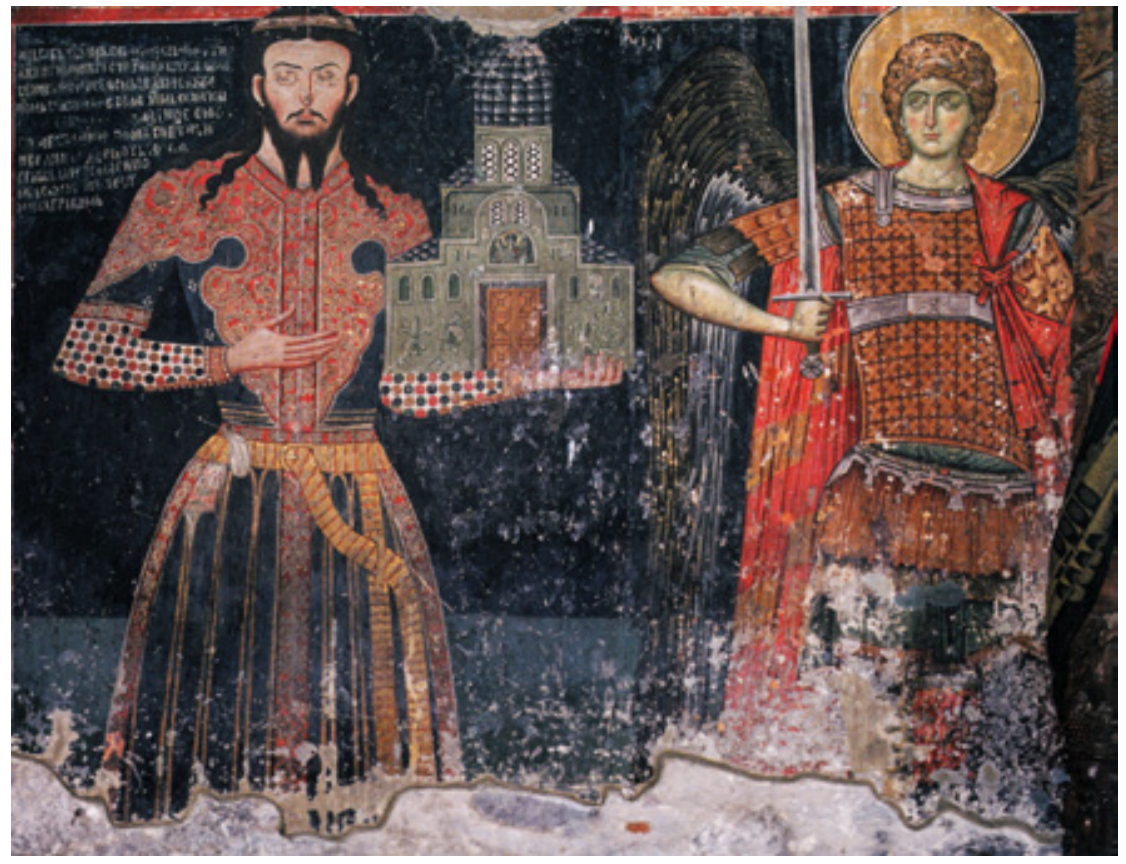

Fig. 2. Holy Archangel Michael in Lesnovo, nave, northern wall, sebastokrator Jovan Oliver and Archangel Michael (photo: I. M. Đorđević) 


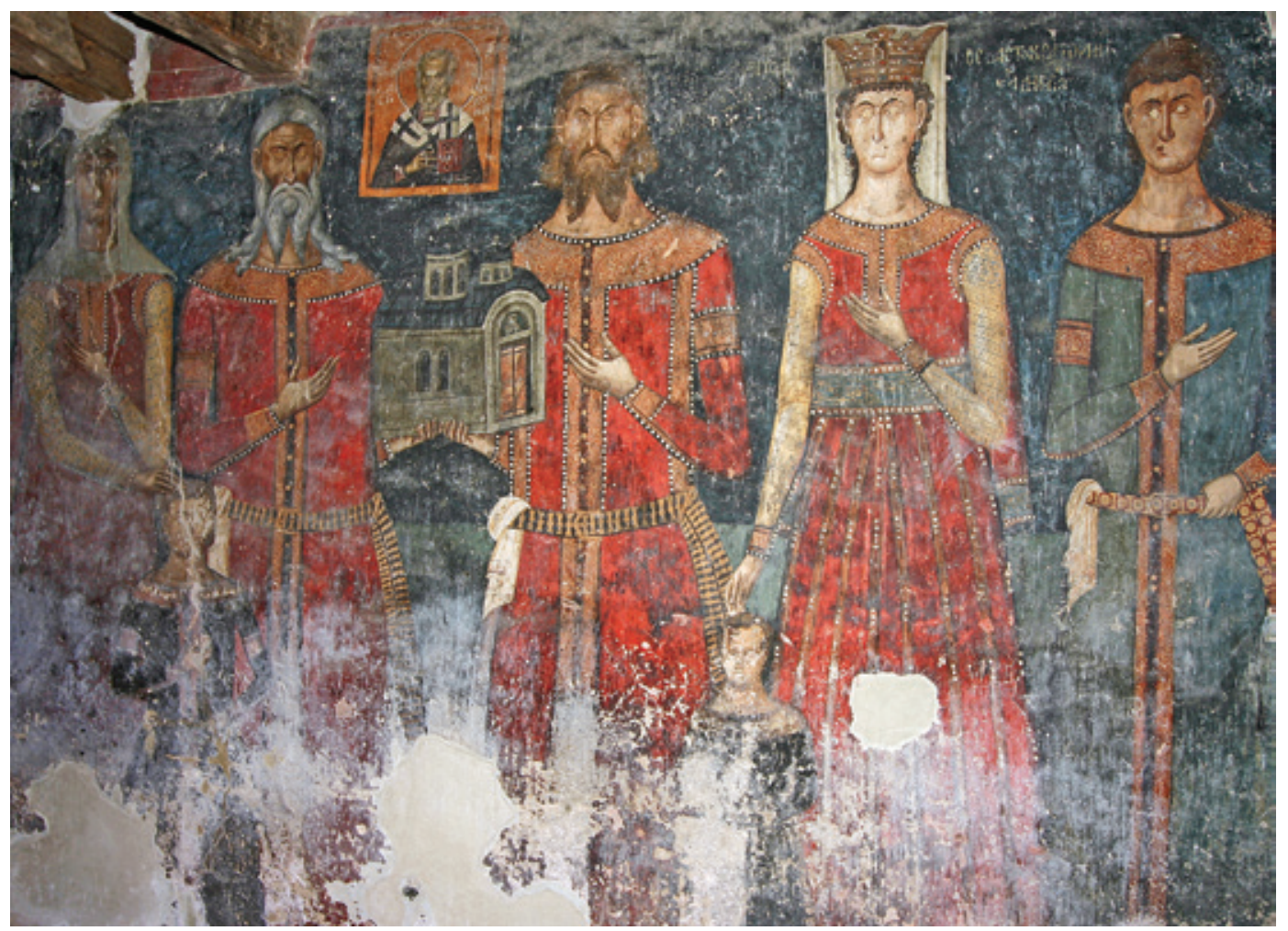

Fig. 3. Saint Nicholas in Psača, narthex, southern wall, ktetorial composition (VoJVODIĆ, Dragan, Danica Popović (eds.). Byzantine Heritage and Serbian Art II. Sacral Art of the Serbian Lands in the Middle Ages, 114, fig. 88)

Prince Paskač and sebastokrator Vlatko jointly submit the model of the church to the patron Saint Nicholas depicted in the form of an icon (ЂорЂЕвић 1994: 172-173, draw. 36, fig. in colour 21-24; РАСолкОскА-НиколОвскА 1995: 43-49, fig. 5), as well as in Ramaća, where an unknown priest and noblemen jointly offer the image of the endowment to the same saint (СТАРодуБцЕв 2016, book II: 216-218, fig. 208, 213, draw. 19). It is quite possible that the noblemen-ktetors in Gornji Kozjak (Ђоръввит 1994: 88, 107) and in Ajnovci (Војводић, ПАвловић 2015: 39) were once portrayed as offering the model of the temple to its patron, but the fragmentary preservation of the fresco paintings makes it impossible to draw reliable conclusions about the original programmatic ensembles.

In Serbian monumental painting, several examples of the ktetorial noblemen compositions have been preserved within which donors are shown as submitting their gift not exclusively to the patron, but to someone else, namely, the Lord. Thus, a certain tepćija, the ktetor of the chapel next to the southern part of the main church of the Monastery of Treskavac (fig. 4), has been painted as presenting a model of the endowment offered to the Lord, 
depicted in the form of the Hand of God blessing him from a segment of the heavens (ЂорЂевИт 1994: 165-166, fig. 32).3 A similar solution was depicted on the north wall of the Kalenić narthex, since above the portrayals of the protovestiarios Bogdan and Despot Stefan, originally presented holding the model of the temple together, a segment of the heavens can be observed, in which, apparently, Christ was once painted, to whom, as we shall see, the aforementioned distinguished nobleman, along with the then current ruler, as mediator, offered a model of his endowment (ВОјВОдић 2006: 270, note 573; СТАРОДУБЦЕв 2016, book II: 164-167, fig. 154, draw. 13).

The latter example shows that the iconographic formula of the joint ktetorship had been applied in the ktetorial compositions of Serbian nobility. Namely, the depictions of two people holding the endowment model together have been preserved in Psača and Ramaća. Although now damaged, the ktetorial noblemen compositions in Kučevište, furthermore, as mentioned, in Kalenić and, it is believed, in Jošanica, were resolved ac-

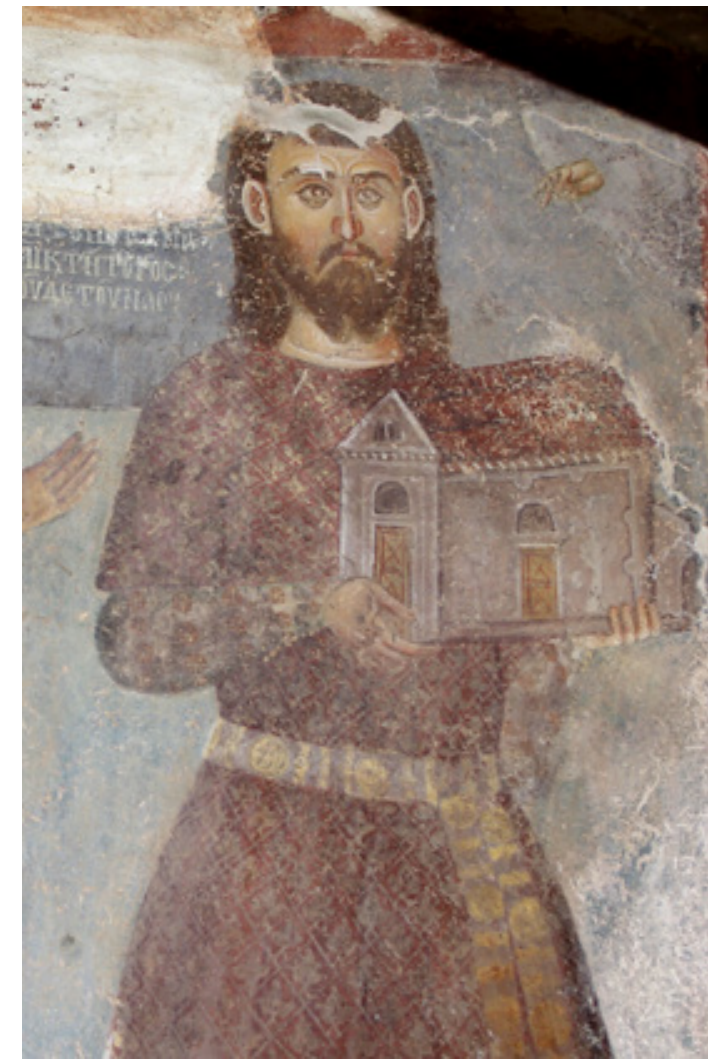

Fig. 4. Treskavac, western façade of the chapel, tepčija-ktetor (ЂОРЂЕВИЋ 1994: fig. 66) cording to the iconography of the joint offering of the gift. When considering the iconography of the joint ktetorship, it is important to emphasise that in most cases the persons responsible for the construction and decoration of the church are presented either independently or accompanied by family members

3 Regardless of the established academic opinion that a nobleman named Gradislav is the ktetor of the south-eastern chapel in the Treskavac Monastery, we maintain the previously stated position that it is still safest to name that endowment holder a certain noblemen with the title of tepćija (ПАвЛовИЋ 2015: 114, note 48). Furthermore, some researchers believe that the tepčija offers the model of his endowment to Christ shown in the lunette above the entrance (ЂурИЋ 1974: 76; МАРИНКОвИЋ 2007: 147), as well as that the ktetor composition is part of the depiction of the Deisis (ТОРЂЕВИЋ 1994: 65, 166; МАРИНКОВИТ 2007: 190, note 534). Ассоrdingly, the prevailing view is that the endowment of the said tepčija was dedicated to Christ, although there are opinions that, like the Monastery of Treskavac, it could have been dedicated to the Holy Mother of God (GoPЂЕВИЋ 1994: 59, 165; МАРИНКОВИЋ 2007: 190, note 532). However, it is difficult to accept the assumption about the identical consecration of the chapel and the temple in which it is located, as well as the opinion that within the church dedicated to the Holy Mother of God there is a chapel, a smaller spatial unit, whose patron is Jesus Christ. 
surrounding the endowment model in the form of a counterpart. In other words, the joint offering of a church model generally signifies a joint ktetorship with participation by persons who were most often in close family relations, ${ }^{4}$ and whose share in the endeavour of patronage may have varied. Ktetorial compositions of Serbian nobility in Kučevište, Psača, Ramaća and, it is assumed, Jošanica, are examples of the iconographic solution of joint ktetorship and indicate that the individuals who participated in the construction and decoration of the church and were related, as such, were depicted surrounding the temple model. In the church of the Presentation of the Holy Mother of God in Kučevište, there exists a portrayal of Marena, and beside her was once a painting of an individual who held the model of the endowment together with her. ${ }^{5}$ Although the identity of that person, as we mentioned before, has been interpreted differently, all researchers agree in the opinion that this is a representation of a member of the noble family responsible for the construction and decoration of that church. In the centre of the group composition on the south wall of the narthex, in Saint Nicholas in Psača, both Prince Paskač and sebastokrator Vlatko are shown as jointly submitting the model of the endowment to the patron saint, Saint Nicholas, represented in the form of an icon (fig. 3). Judging by the positioning of the images of the portrayed individuals and their gestures within the ktetorial composition, it was concluded that Prince Paskač and sebastokrator Vlatko had closest family ties, more precisely, that they represent father and son (ПАвловић 2018: 79-82). ${ }^{6}$ This may have been similarly the case in Ramaća. On the south wall of the middle bay of this temple, an unknown priest and a nobleman were depicted as offering the model of the church to the patron, Saint Nicholas, portrayed emerging from a segment of the heavens. Since the identity of the priest and nobleman from Ramaća remained unknown, their kinship cannot be precisely determined. In the scholarly literature, the assumption had been made that this is a case of close kinship, of probably brothers (СТАРОДУБцЕв 2016, book II: 218), which can also be observed by the emphasised physical similarity between the depicted nobleman and priest. The iconographic formula which represents the joint ktetorship is, presumably, present in the portrayal at Jošanica. On the south wall of the narthex of the church, a noble couple of unknown identity had been depicted (Цветковит et al. 20o8: 46, 49; СТАРОДУБцев 2016, book II: 190-192, draw. 17), originally believed to have held the model of the temple between them (СТАРОдуьцЕв 2016, book I: 120). On the other hand, the individuals portrayed

\footnotetext{
${ }_{4}$ Such a solution is illustrated, for example, by the examples of Stefan Dečanski and Dušan in Dečani, the boyar Radivoje and the Metropolitan of Sofia Kalivit, in Kremikovci (ВојвОдић 1995а: 265-275; КАмвоURоVA 2011-2012: fig. 12).

5 For the appearance of the proposed reconstruction of the ktetorial composition, see РАСОЛКОСКА-НИКОлОВСКА 1985: fig. 12; КАMBOUROVA 2011-2012: fig. 10.

${ }^{6}$ For a different view, i.e. the position that members of two families have been portrayed in Psača, see ЂОРЂЕВИТ 1994: 117.

7 Similarly to the depiction in Ramaća, the ktetor's portrait in the nave of Donja Kamenica shows two male adults and one child. Judging by their physical likeness, it is assumed that they are brothers, but in Donja Kamenica, unlike the example from Ramaća, only one person holds a model of the temple in their hands. For the depiction from Donja Kamenica see ФрФулАновит 2015: 59, fig. 2.
} 


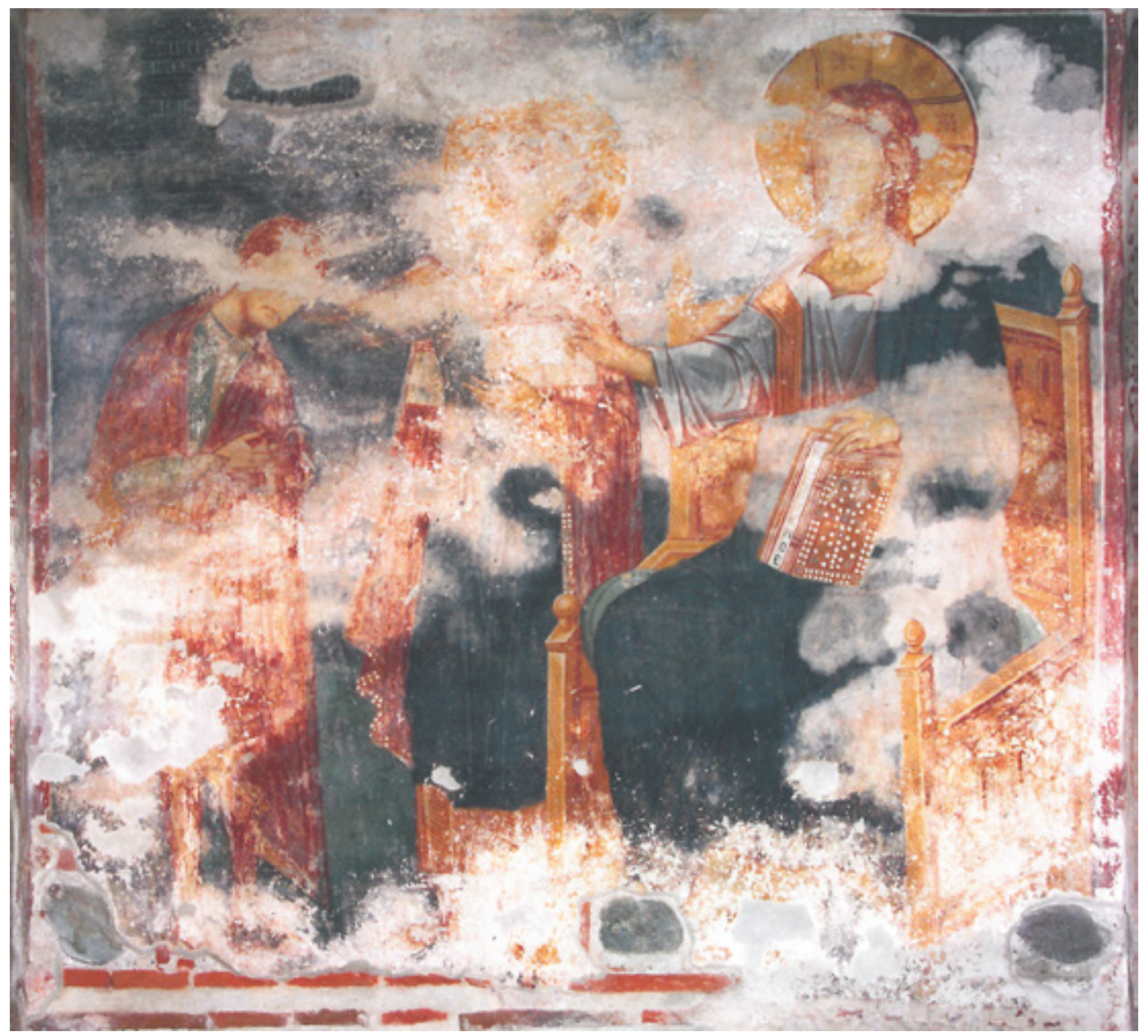

Fig. 5. Dečani, narthex, unknown nobleman (ГАБЕЛИЋ 2011: fig. 5)

surrounding the model of the church (a depiction of two people with the image of an endowment) did not necessarily have to be related, ${ }^{8}$ and such a portrayal does not always need to express their joint effort and care regarding the construction and decoration of the church. ${ }^{9}$ Namely, on the north wall of the narthex of the Church of the Presentation of the Holy Mother of God in Kalenić, protovestiarios Bogdan and Despot Stefan

${ }^{8}$ Such is, for instance, the example from Lapušnja (CVETKOVIĆ 2013: 305-307, fig. 1, 10-11).

9 The ktetorial composition from Ravanica testifies to such a solution. Although the family portrait in Ravanica portrays Princess Milica holding a model of the church with her husband, based on the preserved transcripts of the two founding charters, it is clear that Prince Lazar himself was the ktetor of the Ravanica Monastery (СТАРОДУБЦЕВ 2016, book I: 117). 
Lazarević were presented holding a model of the temple together, although the inscription next to the despot's image does not mention patronage. The ktetor of the church in Kalenić was a respectable nobleman Bogdan, and Despot Stefan is shown here as a mediator in offering the endowment of his subject to the God (Војводит 2006: 270, note 573; СтАРОДУБцЕв 2016, book II: $160-161){ }^{10}$

While in all the aforementioned representations of nobility, with the exception of examples from Kalenić and Jošanica, ktetors offer their gift directly to the patron or Christ, without intermediaries, within compositions of Serbian nobility there are also those whose iconography expressed the concept of intercession. On the left side of the second zone of the southern façade of the narthex at the Church of the Holy Mother of God in Sušica, between the portrayal of the nobleman and the archpriest and, at the same time, behind them, according to old photographs, another figure is shown, most probably of the saintintermediary, preserved only in the bottom part, and not recorded in the scholarly literature, up to now. ${ }^{11}$ The mediator in the offering of noble endowments to the God is also present in the ktetorial compositions in Rudenica, Kalenić and, probably, Naupara, but in these cases he is represented in the person of Despot Stefan Lazarević (Војводић 2006: 270, with literature; book I: 117, 124). The cited examples from the time of Moravian Serbia are especially interesting, both for the presence of the current ruler as a mediator, as for the omission of the model of the church in the hands of the ktetors. The latter solution can be seen in the portrait of the nobleman in Rudenica (fig. 6). Despot Stefan Lazarević holds the "image" of the church in that temple instead of the treasurer Vukašin. The current ruler presents the model of the Rudenica temple to the God instead of the nobleman and, as in Kalenić, represents his subject and mediates in the consecration of his endowment (РАДОЈЧИЋ 1996: 69, 79; ВојвОДИЋ 2006: 270; СТАРОДУБЦЕВ 2016, book II: 160-161, note 776). ${ }^{12}$ Compositions of noblemen based on the concept of intercession could have also been enriched with a special iconographic detail - a gesture of the saint's embrace, and a typical example of such an iconographic solution has been preserved on the north wall of the north-eastern bay of the narthex in Dečani (Војводић 1995a: 282-284, fig. 4, 17; ГАБЕлић 2011: 195-210, fig. 1, 5). Saint George, the patron of the Dečani chapel, is shown before Christ as the mediator and representative of the young nobleman. He embraces the nobleman with his right hand, and with a gesture of the left he recommends him and brings him forth, slightly bowing, to the Savior, who responds to the gift of the nobleman, a difficultto-discern object in his left hand, with a blessing (fig. 5). ${ }^{13}$ A similar solution was achieved in Jošanica. Along with the unknown nobleman-ktetor, a holy warrior was portrayed, presumably

10 For a different view, see ЦвЕтКОвић 2009: 79-98.

${ }_{11}$ At this point, it is difficult to make any assumptions about her identity. I would like to express my gratitude to Professor Dragan Vojvodić for providing the photographic recording and pointing out the representation of the abovementioned individual on the façade of the church in Sušica.

${ }_{12}$ For a different opinion see ЦветКОвић 2009: 79-98.

${ }_{13}$ In that instance, the researchers noticed a bag with money, a hat or a reliquary. For the review of literature on this subject (ВОЈВОДИЋ 1995а: 282-284; ГАБЕЛИЋ 2011: 203-207). 


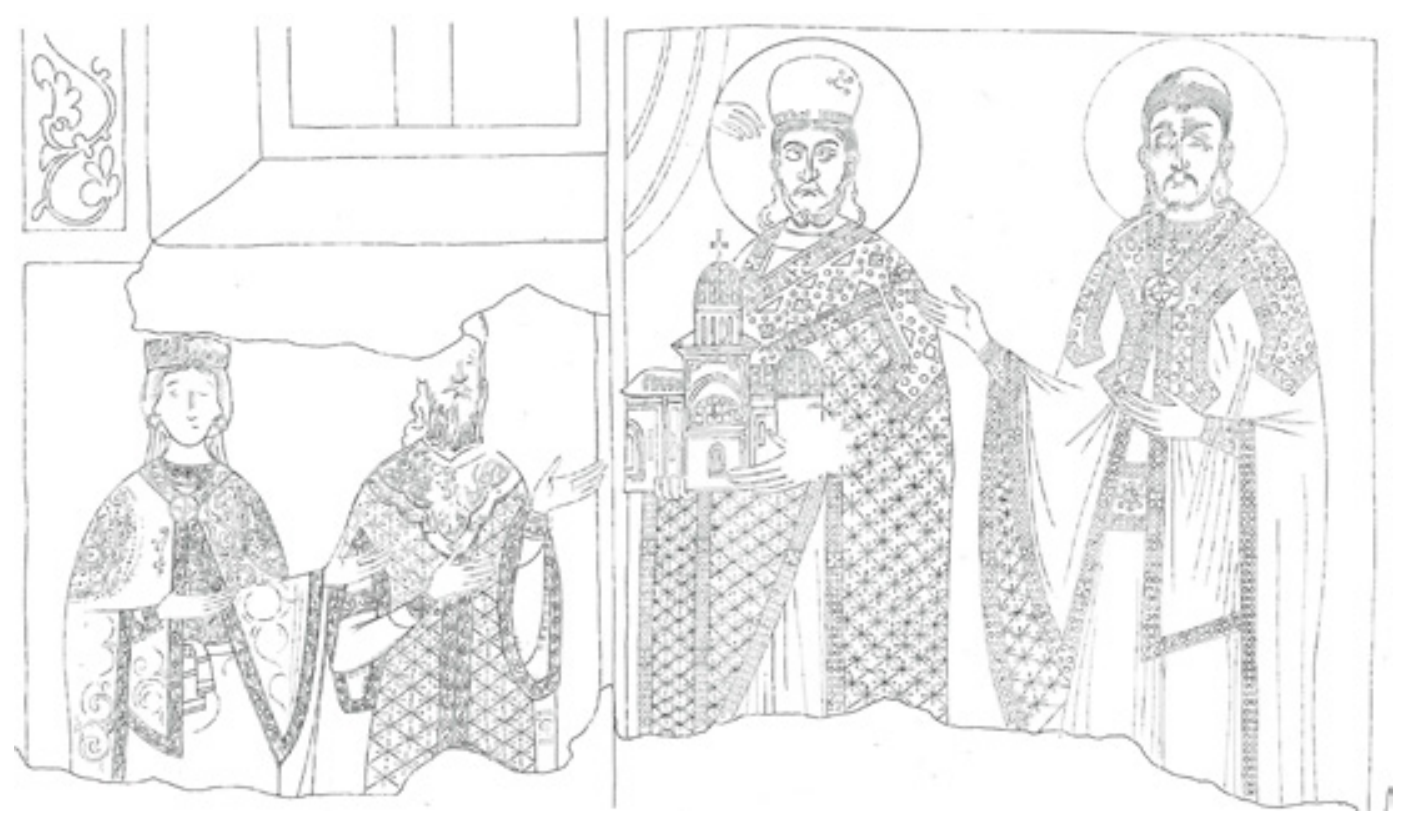

Fig. 6. Rudenica, nave, southern wall, treasurer Vukašin and his wife Vukosava, western wall, despot Stefan Lazarević and Vuk Lazarević (СТАРОдуБцев 2016, book II: 76, draw. 6)

the patron of the church, Saint Demetrios, who places his hand on the man's shoulder (ЦвEткОвИЋ et al. 2008: 46). ${ }^{14}$

The example from Rudenica is not singular in Serbian medieval painting in the omission of the model of the church in the hands of the ktetors. Namely, some Serbian noblemen, responsible for the construction and/or renovation, that is, fresco painting of temples or some spatial units within them, were sometimes depicted without the image of the church, as in the case of Despot Jovan Oliver in the narthex of Lesnovo and the chapel of Saint John the Forerunner in Saint Sophia, in Ohrid, as well as kaisar Novak in Mali Grad on Prespa - fig. 7 and Stefan Musić in Nova Pavlica. The absence of the endowment model in the depiction of Despot Jovan Oliver in the narthex of the church in Lesnovo, the individual engaged in the construction and fresco painting of that part of the Lesnovo temple (ЂОРЂЕВИЋ 1994: 159-160, fig. in colour 17; ГАБЕЛИЋ 1998: 169-172, Т. XLIII - XLIV, fig. 78-79) can be explained by the fact that the said nobleman, with a gift in his hand, had already been depicted in the nave of Lesnovo, as well as by an assumption that a

${ }^{14}$ Judging by the position of the fragmentarily preserved figure of the mediating saint, it is very probable that he was originally embracing the nobleman on the façade of the Church of the Holy Mother of God in Sušica. Hence, according to the presence of the gesture of embracing the saint mediator, the composition of nobles from Sušica would be similar to the examples from Dečani and Jošanica. Professor Dragan Vojvodić, whom we thank on this occasion, drew our attention to this detail regarding the composition of nobles from Sušica. 


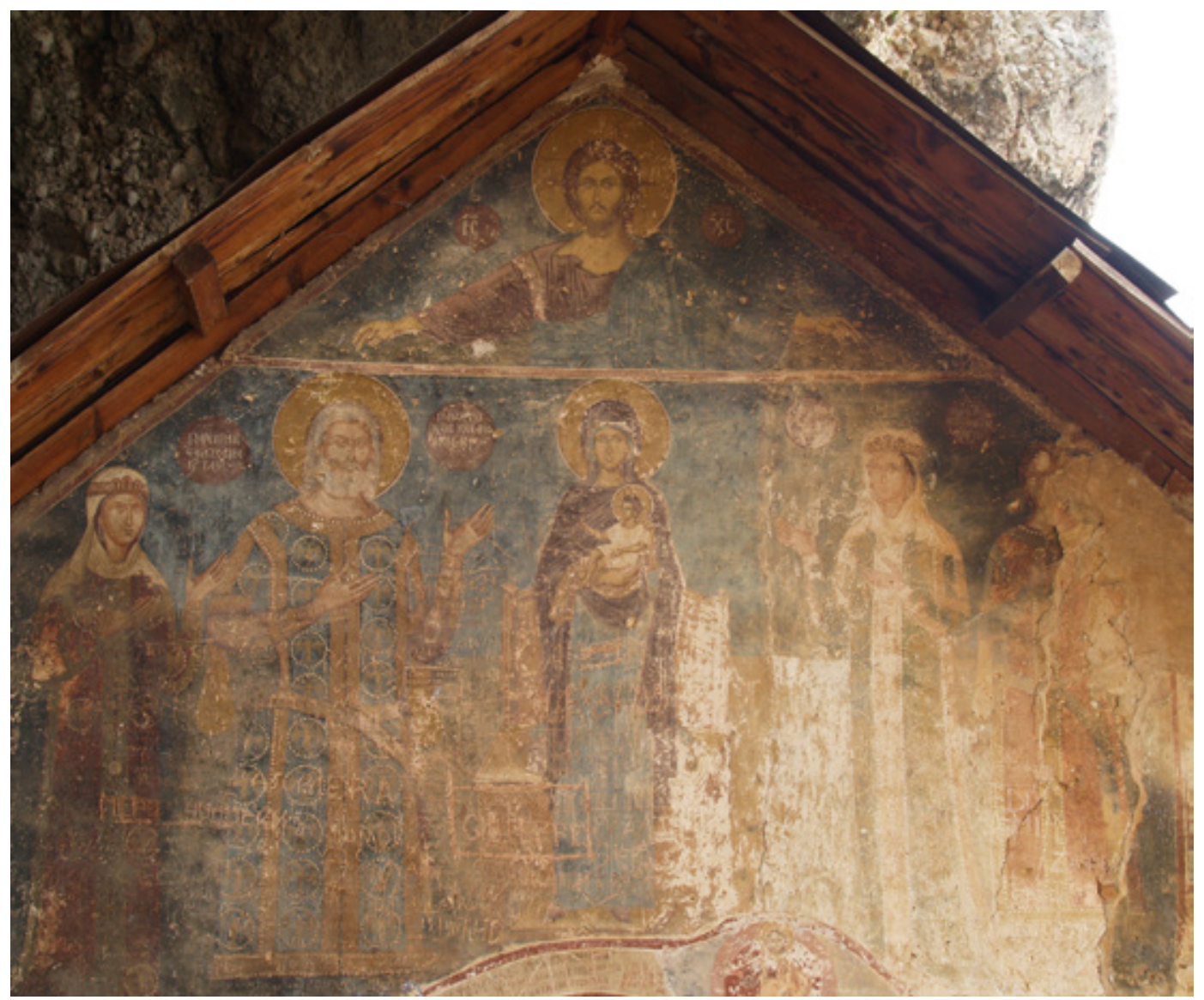

Fig. 7. Mali Grad on Prespa, western façade, ktetorial composition (photo: I. M. Đorđević)

repeated portrayal of Jovan Oliver with the "image" of the temple in his hand in the subsequently added narthex was not necessary. When it comes to the Church of the Holy Mother of God on the island of Mali Grad on Prespa, it is important to keep in mind that kaisar Novak, the second ktetor of that cave temple, renovated the older building, actually, purely enlarged the walls of the existing object and, in some places, decorated the walls with new frescoes (Ђурић 1975: 31-37; BogEvsKA-CAPUANO 2015: 372-429) and, accordingly, the cited nobleman did not necessarily have to be portrayed with a model of the church in his hands (fig. 7). ${ }^{15}$ Furthermore, depicted without the model of the church in his hands, but holding a bent scroll, is Despot Jovan Oliver, the ktetor of the frescoes

${ }_{15}$ When it comes to portraying nobility, the restorers of older buildings or individuals responsible only for the fresco paintings of a temple could be presented with the model of the church in their hands, as in the case of the nobleman in Gornji Kozjak (ЂорЂЕвић 1994: 138-139, fig. in colour 4), but the "image" of the temple 
in the chapel of Saint John the Forerunner in the Church of Saint Sophia, in Ohrid, which, in portrait ensembles of nobility, considering the preserved examples, represents a unique solution (ГРОздАнов 1980: 62-64, draw. 9, fig. 44; ЂорЂевй 1994: 158, draw. 39; Војводит 2006: 42). On the other hand, in Nova Pavlica, Stefan Musić is depicted without the "image" of his endowment, although in the accompanying inscription he is clearly marked as the ktetor (СТАРодубцев 2016, book II: 55). Such a solution is rare, but it was not uncommon in Byzantine art. For example, this was the way voevod Michael is depicted in the church of Saint Paraskevi in Monodendri, the ktetor of the Church of the Holy Mother of God in Kakopetria, in Cyprus, the Moldavian vojvoda Petar Rareš in the katholikon of the Monastery of Saint Dionysius, and their merits highlighted in the ktetor inscriptions, or the accompanying ones. ${ }^{16}$

The iconographic motif of the Blessing of God, in the art of Byzantium, and the countries under its cultural influence, applied to the representations of aristocrats, archpriests, and monks, is also present in Serbian compositions of nobles (Војводић 2006: 191). The oldest depiction of nobility under the blessing of Christ in Serbian painting has been preserved in the frescoes of the Church of Saint George at Pološko. A semicircle of divine light, from which the Hands of God emerge, had been depicted above the main entrance to the temple, nowadays above the portal that leads from the narthex to the nave. They bless the members of a distinguished noble family: Jovan Dragušin and his wife shown on the left side of the composition, as well as their son, and the nun Marija, Dragušin's mother and the ktetor of the temple, on the right side (ПАвловић 2015: 109, fig. 2-3). Under the blessing hand of Christ to which a certain tepčija offers a model of his endowment, this nobleman has been depicted on the western façade of the chapel next to the southern part of the main church of the Treskavac Monastery, the construction of which he is credited for (fig. 4). The depiction of the Blessing of God is also preserved in the fresco paintings of Mali Grad on Prespa. Painted on the western façade of this temple, in a segment of the heavens, is a figure of Christ, with outstretched arms, blessing kaisar Novak and members of his family (Ђурић 1975: fig. 4; BogevsкA-САРuANo 2015: 384, fig. 67, ill. 59). Thus, the figure of Christ or the Hand of God from a segment of the heavens sends blessings to the aforementioned Serbian nobles of different ranks, their wives and children, and thus, they receive confirmation of their social status and acts of patronage (Војводит 2006: 191).

In Serbian medieval art, posthumous portraits of aristocracy represent a special group: depictions of Jovan Dragušin in the Church of Saint George at Pološko (Павловит 2015: 113, fig. 4-5), sebastos Jovan Prosenik in Saint Sophia, in Ohrid (Грозданов 1980: 61-62, draw. 8, fig. 39, 40; ЂорЂевит 1994: 165, fig. in colour 18), and Ostoja Rajaković at the Holy Mother of God in Peribleptos, in Ohrid (Бурит 1974: fig. 85; Грозданов 1980:

could have been omitted, as we can see, for example, in the instance of portraits of aristocracy in Saint Mamas in Louvaras in Cyprus (STYLIANOU, StYlianou 1985: 246-247, fig. 140).

${ }^{16}$ For the abovementioned examples see Stylianou, Stylianou 1985: 76, fig. 31; AxeImastor-ПотA-

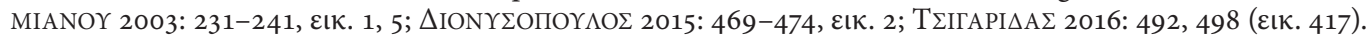


153-154, fig. 165). The said noblemen are portrayed with their hands raised in prayer, and the inscriptions next to their images clearly indicate that these are posthumous portraits, as well as the fact that Ostoja Rajaković was portrayed in the arcosolium above his grave in the narthex of Ohrid's Peribleptos. Although in Eastern Christian art the deceased are usually represented in posthumous portraits with their arms crossed on their chests (SEMOGLOU 1995: 5-11), analogies to the cited Serbian examples can be found in Byzantine posthumous depictions in which nobles are also depicted with raised hands in prayer (Dimitrije in the Church of Saint Panteleimon in Ohrid, Jovan Asen in the icon that was located in the Monastery of Mega Spelaion, several members of the ktetor's family in Staničenje, for example). ${ }^{17}$

We could single out as a special group the Serbian sets of portraits on which the figures of nobles are of extremely small dimensions, significantly reduced in relation to the representations of Christ, the Holy Mother of God or the saint next to whose feet they are depicted. One such example, now greatly damaged, has been preserved in the Church of the Presentation of the Virgin in Lipljan. The niche in the western part of the north wall of the nave of this temple is adorned with a standing representation of an unknown noblemanbenefactor, addressing in prayer the archpriest, in whose figure Saint Nicholas can be recognised (Војводић 2013: 149-150; ДАвидов-ТемЕРИнски 2014: 31-33, fig. 14) ${ }^{18}$ Furthermore, significantly reduced in size in relation to the figure of the Holy Mother of God, but unlike the example from Lipljan, in deep proskinesis, the basilissa Marija has been depicted in the icon from Meteora (which, in the scholarly literature, is considered actually a part of the former diptych) and on the left wing of the reliquary-diptych kept in Diocesan Museum at Cuenca in Spain. She is portrayed in a kneeling position as a contrite petitioner, as she raises her gaze and hands towards the Holy Mother of God in prayer for her own salvation (Војводић 2007: 385). Despot Toma Preljubović expressed his submission to God in the same way in the depiction that was once on the right wing of the diptych from $\mathrm{Cu}$ enca, whose left counterpart was a depiction of his wife. Apart from the representations of nobility, deep proskinesis is characteristic of the iconography of Serbian and Byzantine portrayals of royalty and common in Byzantine painting of the Palaiologan period, indicating Marija and Toma's belonging to the sinful human race, namely, the imperfection of human nature and its mortality (Војводић 2006: 321; 2007: 385, with literature).

Finally, it is important to point out that a rare iconographic solution in depicting nobility was preserved in the icon of the Doubting of Thomas, which is kept in the Monastery of the Transfiguration at Meteora. At the centre of the composition of that icon is Christ,

${ }_{17}$ On representations in Byzantine art see ГРОзДАНОВ 1980: 35, draw. 3; РАРAмASTORAKIS 1997: 70, fig. 1, 3-5; ПОПОВИЋ, ГАБЕЛИЋ et al. 2005: 98-100, fig. 37, 40-44.

${ }_{18}$ Precisely the fact that the aristocrat was painted in smaller dimensions in relation to Archbishop Nikola is an argument for recognising the representation of the benefactor in the image of this, currently unknown, nobleman. The ktetors of the Lipljan church were originally painted on the western façade, under the portrait of the ruling couple Dušan and Jelena, repeating the iconographic solution achieved several years earlier in the Church of Saint George at Pološko (Војводић 2013: 150; ДАвидов-ТЕмерински 2014: 31-33, 35, fig. 14). 
surrounded by the apostles, and among the group of disciples on Christ's right is Doubting Thomas, touching the teacher's wounds, as well as a female figure dressed in a royal robe in which, although not marked by inscription, the basilissa Marija Angelina Dukena Paleo-

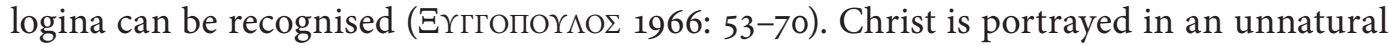
position and with an unusual gesture. Curved to the side, and bent to the left, he places his left hand on the head of the Apostle Thomas, while extending his right hand to the basilissa Marija, touching her crown (ŠEVČENKO 1993-1994: 162-164, fig. 7; CARR 1995: 347; GARgOVA 2011-2012: 369-372, fig. 1; AgORITSAS 2014: 174-175, fig. 1). The depiction of aristocrats next to the apostles within the scene of the Doubting of Thomas is rare, and can also be found in the fresco in the Church of the Holy Cross in Pelendri, Cyprus, where within the scene of the Doubting of Thomas, a married donor couple have been portrayed, in a kneeling position with hands raised in prayer. ${ }^{19}$

The above contemplation on the portraits of nobility had demonstrated that different iconographic solutions were applied within the portrait ensembles of Serbian nobility. Moreover, the preserved examples testifies to the simultaneous presence of several iconographic elements, motifs or formulas within one representation of nobility, which resulted in the creation of more complex ensembles of portraits of aristocrats (Kučevište, Treskavac - fig. 4, Psača - fig. 3, Mali Grad on Prespa - fig. 7, Ramaća, Rudenica - fig. 6, Kalenić and Jošanica). On the whole, most of the iconographic elements, motifs or formulas observed in Serbian portrayals of nobility have been common for the time when they were created, and have analogies among the examples preserved in the art of Byzantium and countries under its cultural influence. Expressly, having in mind the type of portraits, as well as the number of depicted individuals, in Serbian medieval frescoes, as well as in Byzantine painting, in most cases these represent ktetor family portraits. In other words, the depiction of the donor in the act of prayer before the patron to whom he offers his gift without intermediaries is common in the iconography of Serbian ktetorial compositions of nobility (Kučevište, Karan - fig. 1, Dobrun, nave in Lesnovo - fig. 2, Psača - fig. 3, Ramaća, chapel in Treskavac - fig. 4). The images of patrons, similar to the solutions known in Byzantium, are most often presented in the form of a standing figure in the immediate vicinity of the portrayals of the noblemen-ktetors of churches or noblemen-benefactors (Kučevište, White Church of Karan, Dobrun, Mali Grad on Prespa, nave in Lesnovo - fig. 2, chapel of Saint John the Forerunner in Saint Sophia, in Ohrid, the narthex of Dečani - fig. 5, Jošanica).

Just as in the monumental painting of Eastern Christian countries, the Serbian ktetorial compositions of nobility are distinguished by the iconography of joint ktetorship, that is, the iconographic formula which represents joint patronage (Kučevište, Psača - fig. 3, Ramaća and, probably, Jošanica). As in the art of the Byzantine world (despots in the Holy

19 For a different identification of the donor pair see STYLIANOU, STYLIANOU 1985: 231-232; CARR 1995: 345, fig. 11; GARGOVA 2011-2012: 372. 
Virgin Hodegetria in Mystras and Donja Kamenica, dignitaries in the typicon of the Holy Virgin of True Hope, members of the aristocratic family in Donja Kamenica, voevod Michael and his son George in the Church of Saint Paraskevi at Monodendri in Epirus, Sofian boyar Radivoj in Kremikovci, archpriest in Saint Demetrios in Mystras, monks in Bačkovo, Staničenje and Donja Kamenica, etc.), ${ }^{20}$ as well as in Serbian frescoes, nobility could be depicted under the blessing hands of Christ (Pološko, Treskavac - fig. 4, Mali Grad on Prespa - fig. 7). Furthermore, the portrayals of the basilissa Marija and her husband, Toma Preljubović, in position of prayer in the icon from the Monastery of the Transfiguration at Meteora and the reliquary-diptych kept in Cuenca, point towards a reliance on contemporary iconographic trends since the then current form of prokinesis had been applied.

In contrast, certain iconographic solutions applied to portraits of Serbian nobility are rare and unusual. Thus, compositions of nobles based on the concept of intercession with the gesture of embracing a saint-mediator were not frequent in the iconography of Byzantine portrayals of ktetors or benefactors, ${ }^{21}$ so Serbian examples preserved in the frescoes of Dečani (fig. 5) and Jošanica are especially interesting. Also, the offering of the church model to the patron depicted in the form of an icon, as in the Church of Saint Nicholas in Psača, remains extremely rare (fig. 3). Nevertheless, we can find analogies to the solution from Psača among the older monuments in Kintsvisi and Betania. In the former Georgian temple, a representative of an aristocratic family offers his gift to Saint Nicholas, presented as an icon, while in the latter, Sumbat Orbeli presents a model of the church to its patron the Holy Mother of God, who is also depicted in the form of an icon (EASTMOND 1998: 144, 156, fig. 78). Furthermore, the depiction of donors within the gospel scene in the icon of the Doubting of Thomas, which is kept in the Monastery of the Transfiguration at Meteora, is a special solution in Serbian medieval painting. On the whole, the introduction of donor figures into New Testament scenes was very rare in manuscripts and icon painting, as well as in the monumental painting of the late Palaiologan period. ${ }^{22}$ The few examples of such a solution, apart from the already cited scene of the Doubting of Thomas in the Cypriot church of the Holy Cross in Pelendri, include the representation of the Crucifixion of Christ in the chapel in Pyrga, also in Cyprus, with figures of a married couple depicted kneeling at the bottom of the cross (CARR 1995: 347, fig.14; GARGOVA 2011-2012: 372), however, the portrayal of the figures of donors in this manner never became a widespread and dominant practice in Orthodox art.

Finally, having in mind the usual iconography in the portraits of nobility, depictions of the nobleman-ktetor with a bent scroll in his hands (Despot Jovan Oliver in the Forerunner's chapel in Ohrid's Saint Sophia) and the presence of the current ruler, Despot

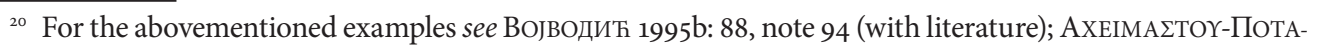
MІАNOY 2003: 231-241, عાк. 1, 5, 6; ПОПОВИЋ, ГАБЕЛИЋ et al. 2005: 93-94, fig. 40; ФРФУЛАНОВИЋ 2015: 45-49, 61-62.

${ }^{21}$ For examples of the embrace of the saint in Byzantine mural painting and miniature, see ĐURIĆ 1999: 95-96; ПОПОВИЋ, ГАБЕЛИЋ et al. 2005: 84-85; КАмВОUROVA 2011-2012: fig. 12.

${ }^{22}$ GARGOVA 2011-2012: 372. On the other hand, the introduction of the portrayals of donors in gospel scenes was more common in Western art. Regarding this, with accompanying literature, see CARR 1995: 347, note 48. 
Stefan Lazarević as a mediator in offering a model of a church of his subjects to the God, in noble endowments at the time of Moravian Serbia, more precisely in Rudenica - fig. 6, Kalenić, and presumably in Naupara, as well, represent a unique solution not only in Serbian medieval painting, but also in the art of the Byzantine world, in general. Therefore, it can be concluded that the portrait ensembles of Serbian nobility maintain a special place in Byzantine art and the countries under its cultural influence, both in terms of diverse iconography, as well as the appearance of unusual and unique solutions.

\section{LITERATURE}

Војводић, Драган. „Владарски портрети српских деспота.” У: Ђурић, Војислав Ј. (ур.). Манаситир Ресава. Истиорија и уметиности. Деспотовац: Народна библиотека „Ресавска школа” (VOJVODIĆ, Dragan. „Vladarski portreti srpskih despota.” U: ĐURIĆ, Vojislav J. (ur.). Manastir Resava. Istorija i umetnost. Despotovac: Narodna biblioteka „Resavska škola”), 1995, 65-95.

Војводић, Драган. „Портрети владара, црквених достојанственика и племића у наосу и при-

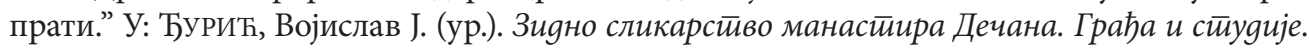
Београд: CAHУ (VOJVODIĆ, Dragan. „Portreti vladara, crkvenih dostojanstvenika i plemića u naosu i priprati." U: ĐURIĆ, Vojislav J. (ur.). Zidno slikarstvo manastira Dečana. Građa i studije. Beograd: SANU), 1995a, 265-297.

Војводић, Драган. Иgејне основе срйске влаgарске слике у среgюем веку. Београд, 2006. (непубликована докторска дисертација) (VOJVODIĆ, Dragan. Idejne osnove srpske vladarske slike u srednjem veku. Beograd, 2006. (nepublikovana doktorska disertacija).

Војводић, Драган. „О живопису Беле цркве каранске и сувременом сликарству Рашке.” Зоīpaø (VOJVODIĆ, Dragan. „O živopisu Bele crkve karanske i suvremenom slikarstvu Raške.” Zograf) 31 (2006-2007): 135-151.

Војводић, Драган. „’Обавијен земаљском сликом'. О представама византијских и српских средњовековних владара у проскинези.” Црквене стиyguje (VoJVODIĆ, Dragan. „'Obavijen zemaljskom slikom'. O predstavama vizantijskih i srpskih srednjovekovnih vladara u proskinezi." Crkvene studije) 4 (2007): 379-394.

Војводић, Драган, Драгана Павловић. „Црква 'Тамница' код Ајноваца у позном средњем веку.” Косовско-метиохијски зборник (VoJvODIć, Dragan, Dragana Pavlović. „Crkva 'Tamnica' kod Ajnovaca u poznom srednjem veku.” Kosovsko-metohijski zbornik) 6 (2015): 9-6o.

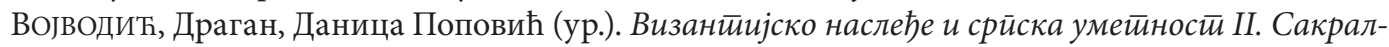

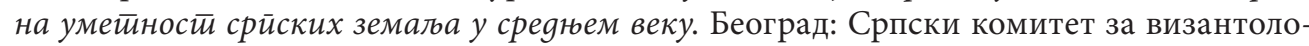
гију, ЈП Службени гласник, Византолошки институт CAHУ (VoJVODIĆ, Dragan, Danica Popović (ur.). Vizantijsko nasleđe i srpska umetnost II. Sakralna umetnost srpskih zemalja u srednjem veku. Beograd: Srpski komitet za vizantologiju, JP Službeni glasnik, Vizantološki institut SANU), 2016.

ГАБЕЛИЋ, Смиљка. Манасӣир Лесново. Истиорија и сликарсӣво. Београд: Стубови културе (GABELIĆ, Smiljka. Manastir Lesnovo. Istorija i slikarstvo. Beograd: Stubovi kulture), 1998. 
ГАБЕЛИЋ, Смиљка. „Слика властелина у Дечанима.” У: МЕДАКОвић, Дејан, Цветан Грозданов (ур.). На тираіовима Војислава J. Ђурића. Београд: САНУ (GABELIĆ, Smiljka. „Slika vlastelina u Dečanima." U: MEDAKović, Dejan, Cvetan Grozdanov (ur.). Na tragovima Vojislava J. Đurića. Beograd: SANU), 2011, 195-210.

ГрОзДАнов, Цветан. Охрияско зияно сликарстиво XIV века. Београд: Институт за историју уметности, Филозофски факултет (GROZDANOV, Cvetan. Ohridsko zidno slikarstvo XIV veka. Beograd: Institut za istoriju umetnosti, Filozofski fakultet), 1980.

ДАвИдов-ТемеРИнСкИ, Александра. Црква Вавеgеъа Боіоородице у Лийлану. Београд: Републички завод за заштиту споменика културе (DAVIDOV-TEMERINSKI, Aleksandra. Crkva Vavedenja Bogorodice u Lipljanu. Beograd: Republički zavod za zaštitu spomenika kulture), 2014.

ЂорЂЕвИћ, Иван. Зияно сликарсииво срйске власиеле у gоба Неманића. Београд: Филозофски факултет (ĐoRĐEVIĆ, Ivan. Zidno slikarstvo srpske vlastele u doba Nemanjića. Beograd: Filozofski fakultet), 1994.

Ђурић, Војислав Ј. Визанйијске фреске у Јуі̄ославији. Београд: Југославија (ĐURIĆ, Vojislav J. Vizantijske freske u Jugoslaviji. Beograd: Jugoslavija), 1974.

Ђурит, Војислав J. „Мали Град - Св. Атанасије у Костуру - Борје.” Зоірафф (ĐURIĆ, Vojislav J. „Mali Grad - Sv. Atanasije u Kosturu - Borje.” Zograf) 6 (1975): 31-49.

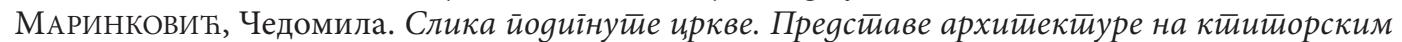

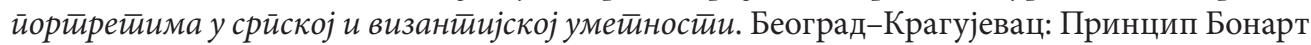
прес, Центар за научна истраживања (MARINKOvić, Čedomila. Slika podignute crkve. Predstave arhitekture na ktitorskim portretima u srpskoj i vizantijskoj umetnosti. Beograd-Kragujevac: Princip Bonart pres, Centar za naučna istraživanja), 2007.

ПАвЛовИћ, Драгана. „Питање ктиторства цркве Светог Ђорђа у Полошком.” Зоіраф (PAVLOVIĆ, Dragana. „Pitanje ktitorstva crkve Svetog Đorđa u Pološkom.” Zograf) 39 (2015): 107-114.

ПАвЛовић, Драгана. „Портрети деце у српском властеоском сликарству у доба Немањића.” Нии и Византиија (PAVlović, Dragana. „Portreti dece u srpskom vlasteoskom slikarstvu u doba Nemanjića." Niš i Vizantija) 16 (2018), 77-91.

Поповић, Марко, Смиљка Габелић, Бранислав Цветковић, Бојан Поповић. Црква Светио̄ Николе у Сйаничеюьу. Београд: Археолошки институт (PoPOVIĆ, Marko, Smiljka Gabelić, Branislav Cvetković, Bojan Popović. Crkva Svetog Nikole u Staničenju. Beograd: Arheološki institut), 2005.

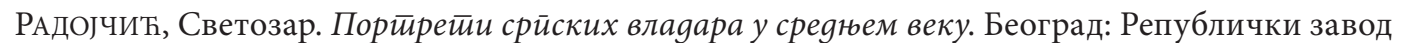
за заштиту споменика културе (RADOJČIĆ, Svetozar. Portreti srpskih vladara u srednjem veku. Beograd: Republički zavod za zaštitu spomenika kulture), 1996.

РАСОЛКОСКА-НиКОЛОВСКА, Загорка. „О ктиторским портретима у цркви Свете Богородице у Кучевишту.” Зоіраф (RASOLKOSKA-NiKOLOVSKA, Zagorka. „O ktitorskim portretima u crkvi Svete Bogorodice u Kučevištu." Zograf) 16 (1985): 41-53.

РАСОЛКОСКА-НИКОЛОВСКА, Загорка. „О историјским портретима у Псачи и времену њиховог настанка.” Зоіраø (RASOLKOSKA-NIKOLOVSKA, Zagorka. „O istorijskim portretima u Psači i vremenu njihovog nastanka." Zograf) 24 (1995): 39-51.

СТАРОдуьцев, Татјана. Срйско зияно сликарсииво у земъама Лазаревића и Бранковића. Кюиіе I u II. Београд: Институт за историју уметности, Филозофски факултет (STARODUBCEV, Tatjana. Srpsko zidno slikarstvo u zemljama Lazarevića i Brankovića. Knjige I i II. Beograd: Institut za istoriju umetnosti, Filozofski fakultet), 2016. 
PORTRAITS OF NOBILITY IN SERBIAN MEDIEVAL ART. A CONTRIBUTION TO THE STUDY OF THEIR...

ФрфулАновић, Драгана. Живойис наоса Боі̄ородичине иркве у Доюој Камениии. Београд, 2015. (необјављени магистарски рад) (FRFUlANOVIĆ, Dragana. Živopis naosa Bogorodičine crkve u Donjoj Kamenici. Beograd, 2015. (neobjavljeni magistarski rad)).

Цветковић, Бранислав, Иван Стевовић, Јелена Ердељан. Манастиир Јошанииа. Београд: Републички завод за заштиту споменика културе (CvETKOVIĆ, Branislav, Ivan Stevović, Jelena Erdeljan. Manastir Jošanica. Beograd: Republički zavod za zaštitu spomenika kulture), 2008.

Цветковић, Бранислав. „Руденице и Каленић: 'двојна', групна или сукцесивна ктиторија?”

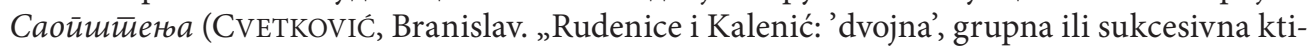
torija?" Saopštenja) 41 (2009): 79-98.

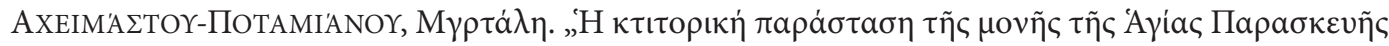

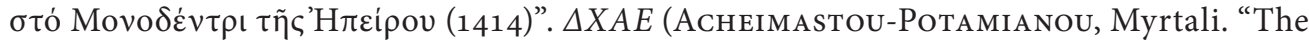
donor representation in the monastery of St Paraskevi at Monodendri, Epirus (1414)". $\triangle X A E)$ 24 (2003): 231-241.

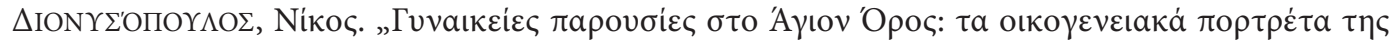

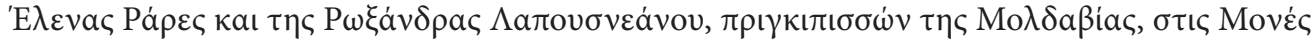

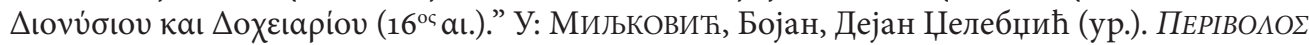
II. Зборник у часй Мирјане Живојиновић. Београд: Византолошки институт, Задужбина светог манастира Хиландара (DiONYSOPOUlOS, Nikos. "Female appearances on Mount Athos: the family portraits of Elena Rares and Roxandra Lapousneanou, princesses of Moldavia in the monasteries of Dionysiou and Docheiariou ( $16^{\text {th }}$ century)." U: MiLjKOVIĆ, Bojan, Dejan Dželebdžić (ur.). PERIVOLOS II. Zbornik u čast Mirjane Živojinović. Beograd: Vizantološki institut, Zadužbina svetog manastira Hilandara), 2015, 469-481.

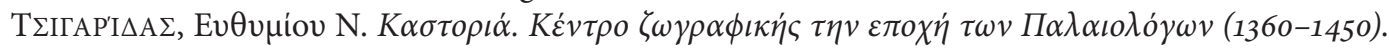

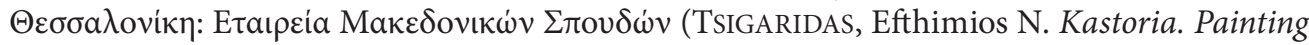
center in the era of the Palaelogan (1360-1450). Thessaloniki: Society for Macedonian Studies), 2016.

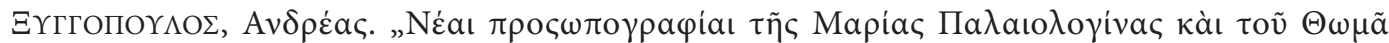

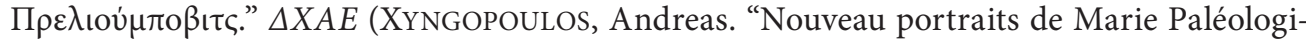
ne et de Tomas Preljubović." $\triangle X A E) 4$ (1966): 53-70.

Agoritsas, Demetrios C. "Maria Angelina Doukaina Palaiologina and her depictions in post-byzantine mural paintings". Зборник раяова Визанйолошкоі инстиитиуйа 51 (2014): 171-181.

BogevsKa-CAPUANO, Saška. Les églises rupestres de la région des lacs d’Ohrid et de Prespa. Milieu de XIII - milieu du XVI $I^{e}$ siècle. Brepols: Turnhout, 2015.

CARR, Annemarie W. "Byzantines and Italians on Cyprus. Images from Art." Dumbarton Oaks Papers 49 (1995): 339-357.

CveTKović, Branislav. "The portraits in Lapušnja and iconography of joint ktetorship." Ниш и Визанüuja 11 (2013): 295-307.

ĐURIĆ, Vojislav J. „Svetiteljev zagrljaj u slikarstvu vizantijskog sveta od XII do XIV veka.” Гoguшник на Софийски Университет „Св. Климент Охрияски”. Центьр за Славяно-византийски проучвания „Иван Дуйчев” 88/7 (1999): 95-96.

EAstmond, Antony. Royal Imagery in Medieval Georgia, Pennsylvania: Pennsylvania State University Press, 1998. 
GARgOVA, Fani. “The Meteora icon of the incredulity of Thomas reconsidered." In: THEIS, Lioba et. al. (ed.). Female Founders in Byzantium and beyond. Wien-Köln-Weimar: Böhlau, 2011-2012, 369-381.

Kambourova, Tania. “Le don de l' église - une affaire de couple?.” In: TheIs, Lioba et. al. (ed.). Female Founders in Byzantium and beyond. Wien-Köln-Weimar: Böhlau, 2011-2012, 213-229.

PAPAMASTORAKIS, Titos. "Ioannes 'redolent of perfume' and his icon in the Mega Spelaion Monastery." Зoīpaø 26 (1997): 65-73.

Semoglou, Athanassios. "Contribution à l'étude du portrait funéraire dans le monde byzantin (14 ${ }^{\mathrm{e}}-16^{\mathrm{e}}$ siècle)." Зoīpaø 24 (1995): 5-11.

STYLIANOU, Andreas, Judith A. Stylianou. The painted churches of Cyprus. Treasures of Byzantine art. London: Trigraph, 1985.

ŠEVČENKO, Nancy P. “The Representation of Donors and Holy Figures on Four Byzantine Icons.” $\triangle X A E 17$ (1993-1994): 157-164.

Vojvodić, Dragan. "Newly discovered portraits of rulers and the dating of the oldest frescoes in Lipljan.” 3oīpaø 36 (2013): 143-155.

\section{Драгана С. Павловић \\ ВЛАСТЕОСКИ ПОРТРЕТИ У СРПСКОЈ СРЕДЬОВЕКОВНОЈ УМЕТНОСТИ. ПРИЛОГ ПРОУЧАВАҢУ ЊИХОВЕ ИКОНОГРАФИЈЕ}

Резиме

Портрети српске властеле, представника различитих нивоа хијерархијске лествице који су настали у XIV и у првој половини XV столећа, сачувани су у српском зидном сликарству и иконопису. Основни циљ рада је подробно проучавање и свеобухватно сагледавање иконографских решења српских властеоских портретских целина. Темељна и детаљна анализа показала је да су она разнолика и чине их различити елементи, мотиви или формуле као што су приношење модела задужбине патрону храма или Господу без посредника (Кучевиште, Каран, Добрун, наос Леснова, Псача, Рамаћа, параклис у Трескавцу), приношење дара патрону или Господу уз заступника (параклис у припрати Дечана, Јошаница, Руденица, Каленић и, вероватно, Наупара), иконографија „двојног ктиторства” (Кучевиште, Псача, Рамаћа и, вероватно, Јошаница), приказивање властелина-ктитора без модела храма (припрата Леснова, Мали Град на Преспи, Нова Павлица и Руденица), иконографија Христовог благослова (Полошко, параклис у Трескавцу, Мали Град на Преспи), иконографија дубоке проскинезе (икона из манастира Преображења на Метеорима и реликвијар-диптих који се чува у Куенки), постхумни властеоски портрети (Јован Драгушин, севаст Јован Просеник, Остоја Рајаковић) и приказивање донатора унутар јеванђељских сцена (икона Неверовања Томиног коja се чува у манастиру Преображења на Метеорима). На представама српских властелина понекад је примењен један од поменутих елемената, мотива или формула, док је на неким долазило до здруживања два решења и, истовремено, стварања сложенијих иконографских целина (Кучевиште, Трескавац, Псача, Мали Град на Преспи, Рамаћа, Руденица, Каленић и Јошаница). 
Иконографски модели примењени на портретима српске властеле у зидном сликарству средњовековних цркава и у иконопису представљају спој како старих узора, тако и нових решења. Већина од њих уобичајена су за време у којем настају и имају аналогије међу бројним примерима сачуваним у уметности Византије и земаља под њеним културним утицајем: приказ ктитора пред патроном коме приноси модел храма уз посредника или без посредника, потом иконографија „двојног ктиторства”, Христовог благослова и дубоке проскинезе, те приказивање властелина-ктитора без модела храма, као и постхумни властеоски портрети. Поједина су пак ретка (властеоске композиције засноване на концепту заступништва уз гест загрљаја светитеља-посредника, приношење модела задужбине патрону приказаном у виду иконе, приказивање донатора унутар новозаветних сцена) или јединствена (приказ властелина-ктитора са свитком у рукама и појава актуелног владара као посредника у приношењу задужбина својих поданика). По разноврсној иконографији и појави особених решења портрети српске властеле имају нарочито место у средњовековној уметности земаља православног света.

Кључне речи: Србија, властела, иконографија, портрет, зидно сликарство, иконопис. 